\begin{tabular}{|l|l|l||}
\hline \multicolumn{2}{|c|}{ PublisherInfo } \\
\hline \hline PublisherName & $:$ & BioMed Central \\
\hline \hline PublisherLocation & $:$ & London \\
\hline \hline PublisherImprintName & $:$ & BioMed Central \\
\hline \hline
\end{tabular}

\title{
Bacteria fix DNA like mammals
}

\begin{tabular}{||l|l|l||}
\hline \multicolumn{2}{|c||}{ ArticleInfo } \\
\hline \hline ArticleID & $:$ & 5012 \\
\hline \hline ArticleDOI & $:$ & $10.1186 /$ gb-spotlight-20041025-01 \\
\hline \hline ArticleCitationID & $:$ & spotlight-20041025-01 \\
\hline \hline ArticleSequenceNumber & $:$ & 75 \\
\hline \hline ArticleCategory & $:$ & Research news \\
\hline \hline ArticleFirstPage & $:$ & 1 \\
\hline \hline ArticleLastPage & $:$ & 3 \\
\hline \hline & $:$ & RegistrationDate : 2004-10-25 \\
ArticleHistory & $:$ & OnlineDate $: 2004-10-25$ \\
\hline \hline ArticleCopyright & $:$ & BioMed Central Ltd2004 \\
\hline \hline ArticleGrants & $:$ & \\
\hline \hline ArticleContext & $:$ & 130595511 \\
\hline \hline
\end{tabular}


Bacteria and mammals may use similar mechanisms in a major yet poorly understood DNA repair pathway, suggests a report in the October 22 Science (Science 2004, 306:683-685).

In theory, coauthor Aidan Doherty of the University of Sussex in Brighton told us, this system - uses of which are the subject of a patent filed by the University of Cambridge - should enable the cloning of any DNA fragments, regardless of the structure of the ends, and has great potential for the generation of random DNA libraries.

Non-homologous end joining (NHEJ) is the main pathway for resection and repair of DNA doublestrand breaks (DSBs) with incompatible ends in mammalian cells. The mechanisms required in NHEJ are poorly understood. Many DSBs require processing by polymerases and nucleases to produce ligatable termini. The Mycobacterium tuberculosis DNA repair ligase, Mt-Lig, has domains exhibiting significant homology with polymerases and possibly nucleases, suggesting it might prove a model for NHEJ.

Doherty's team found that purified recombinant Mt-Lig was an efficient DNA-dependent DNA polymerase in template-dependent primer extension assays and similarly acted as a DNA-dependent RNA polymerase. The researchers also found Mt-Lig possessed 3' to 5' single-strand DNA exonuclease activity, progressively digesting the $3^{\prime}$ but not the $5^{\prime}$ single strand tails of partial duplexes until reaching the double-strand region.

In addition, in polymerization assays with oligonucleotides that produce a nonligatable 1-nt gap upon alignment, Mt-Lig efficiently filled in the gap with no detectable strand displacement synthesis. Mt-Lig used adenosine triphosphate (ATP) and, to a lesser extent, dATP to extend single-strand DNA, demonstrating terminal transferase activity, which is implicated in NHEJ.

The researchers also found that Mt-Lig could join aligned DNA duplexes possessing a 1-nt 3' flap adjacent to a 3-nt gap. Sequencing of ligated junctions in equivalent assays with substrates with a 3-nt flap adjacent to a 5-nt gap showed the microhomology sequence was retained and bases complementary to the template strand replaced the mismatched flap.

"It's just amazing how there are so many activities in one protein. It should prove quite interesting to dissect it to find out how its component parts can catalyze so many different events typically separated in eukaryotes," Steve Kowalczykowski of the University of California at Davis, who did not participate in this study, told us.

The researchers also looked at the Mt-Ku homodimer, which stimulates Mt-Lig to join fully complementary ends, using a PCR-based plasmid repair assay. They found that introducing plasmids that express Mt-Ku and Mt-Lig restored NHEJ to about half its level in wildtype yeast. As prokaryotes lack histones, this Mt activity suggests a specific histone interaction is not required during NHEJ.

"Over the last few years, it has been suggested that many other proteins, including histones that package our DNA, are required for the actual DSB repair process," Doherty said. "It was a great surprise 
to observe that we could knock out the DSB repair complex in a eukaryotic organism such as yeast and replace it with the prokaryotic equivalent."

"Although not proven, this work suggests that RNA could be used to repair DSBs probably as a shortterm measure," Doherty said.

"Potentially, this bacterial system with only two proteins could be used to understand enzymology and details of repair much more easily than with the human cell system, which presumably has a whole range of proteins," Steve Jackson of the University of Cambridge, who did not participate in this study, told us.

Eugene Koonin of the National Center for Biotechnology Information in Bethesda, Md., who did not participate in the study, noted while there were currently no indications primase was involved in eukaryotic DSB repair, Mt-Lig is actually most homologous to eukaryotic primases, and he suggested primases might bear investigation in future NHEJ studies. Doherty and colleagues note eukaryotic primases do share significant homology with the Pol X family of nucleotidyl transferases active in NHEJ.

Jackson also said the system had the potential for biotechnology applications in cloning DNA fragments that do not require compatible ends.

\section{References}

1. Science, [http://www.sciencemag.org]

2. Aidan Doherty, [http://www.sussex.ac.uk/gdsc/]

3. Steve Kowalczykowski, [http://microbiology.ucdavis.edu/sklab/kowalczykowskilab.htm]

4. Weitzman J: Weeding out functions for Ku Genome Biology January 6, 2003., [http://genomebiology.com/researchnews/default.asp?arx_id=gb-spotlight-20030106-02]

5. Steve Jackson, [http://science.cancerresearchuk.org/research/loc/cambridge/wellcome_cr_uk/ jacksons/]

6. Eugene Koonin, [http://www.ncbi.nlm.nih.gov/CBBresearch/Koonin/] 